\title{
Herpetofauna of Cayo Carenas, Cienfuegos Bay, South-central Cuba
}

\author{
Tomás M. Rodríguez-Cabrera ${ }^{1}$, Alejandro M. Rodríguez González², and Javier Torres ${ }^{3}$ \\ 1Sociedad Cubana de Zoología, La Habana, Cuba (tomasmichel.rodriguez@gmail.com) \\ ${ }^{2}$ Heriberto Duquesne, Remedios, Villa Clara 54310, Cuba (alejandromichel00@nauta.cu) \\ ${ }^{3}$ Department of Ecology and Evolutionary Biology, University of Kansas, Lawrence, Kansas 66045, USA (javiertorres@ku.edu)
}

Abstract.-The herpetofauna inhabiting the keys in Cienfuegos Bay in south-central Cuba is virtually unknown. Herein we provide the results of the first rapid inventory performed on Cayo Carenas during the summer of 2016. We found 12 reptilian species in seven families on the key. We also discuss the ecology and the most plausible biogeographic origins for some of the species.

$\mathrm{T}$ The Cuban Archipelago harbors the richest reptilian fauna of the insular Caribbean, with over 160 species, $83 \%$ of which are endemic (e.g., Powell and Henderson 2012; Rodríguez et al. 2013; Uetz et al. 2018). The main

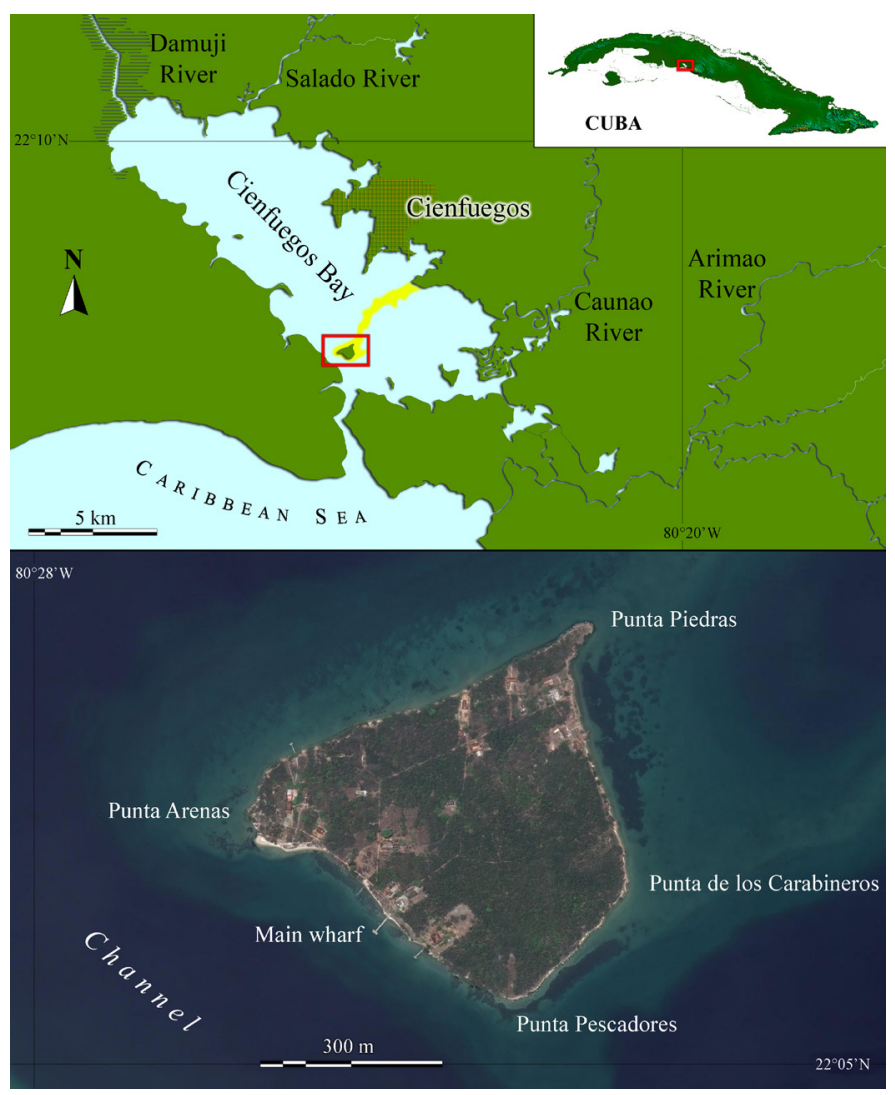

Fig. 1. Maps depicting the location of Cayo Carenas (red square) in Cienfuegos Bay (top); notice the four rivers that flow into the bay and the shallow ( $<2 \mathrm{~m}$ depth) connection to the mainland on the eastern side (yellow strip); and a satellite image showing details of the key (bottom). island of Cuba is surrounded by keys and islets, often with reptilian populations that have been isolated for sufficiently long periods to evolve into different subspecies and species (Estrada 2012). Because of the small population sizes and restricted ranges of many of those taxa, they are highly vulnerable to human disturbance, introduction of exotic species, and stochastic events. Consequently, an understanding of the diversity on those islands, especially those that have been inadequately surveyed, is critical for developing conservation strategies.

Only a few Cuban provinces (La Habana, Mayabeque, Cienfuegos, and Guantánamo) lack offshore keys. However, Cienfuegos has one of the largest bays in the country, with a maximum depth of $40 \mathrm{~m}$ and widths ranging from $18 \mathrm{~km}$ to about $3.5 \mathrm{~km}$. This bay contains some small keys, most of them around the delta of the Caunao River (Fig. 1). Cayo Carenas is the largest of the two limestone keys within Cienfuegos Bay and the only one with remnant primary vegetation. The other limestone key is Cayo Alcatraz, with a very small area (3.7 ha) densely inhabited by humans; indeed, it is disturbed to such an extent that virtually no native vegetation remains. The other keys are formed by marsh deposits with mangroves, an unsuitable habitat for most reptiles. The herpetofauna of these keys has never been studied. Herein we present the results of a rapid inventory carried out on Cayo Carenas during the summer of 2016.

\section{Materials and Methods}

Cayo Carenas (Fig. 1) is composed of biogenic limestone from the Early-Middle Miocene, which suggests that it became detached from the western side of the Cienfuegos Bay, about $0.5 \mathrm{~km}$ away (Pushcharovsky 1988). It is a small (22.3 ha), sub-rhomboidal, low (maximum elevation $2.7 \mathrm{~m}$ ) key 
located near the entrance of Cienfuegos Bay $\left(22^{\circ} 05^{\prime} 03.7^{\prime \prime}-\right.$ $22^{\circ} 05^{\prime} 23.7^{\prime \prime} \mathrm{N}, 80^{\circ} 27^{\prime} 25.9^{\prime \prime}-80^{\circ} 27^{\prime} 48.5^{\prime \prime W}$; WGS 84), on the shipping lane between the city of Cienfuegos and the Jagua Fortress. The key ranges in width from $0.66 \mathrm{~km}$ to
$0.42 \mathrm{~km}$, and has a perimeter of $2 \mathrm{~km}$. With the exception of the westernmost extreme (Punta Arenas), composed of sandy beach, the remaining shoreline is comprised of rocky cliffs (Figs. $2 \& 3$ ). The predominant vegetation is semideciduous

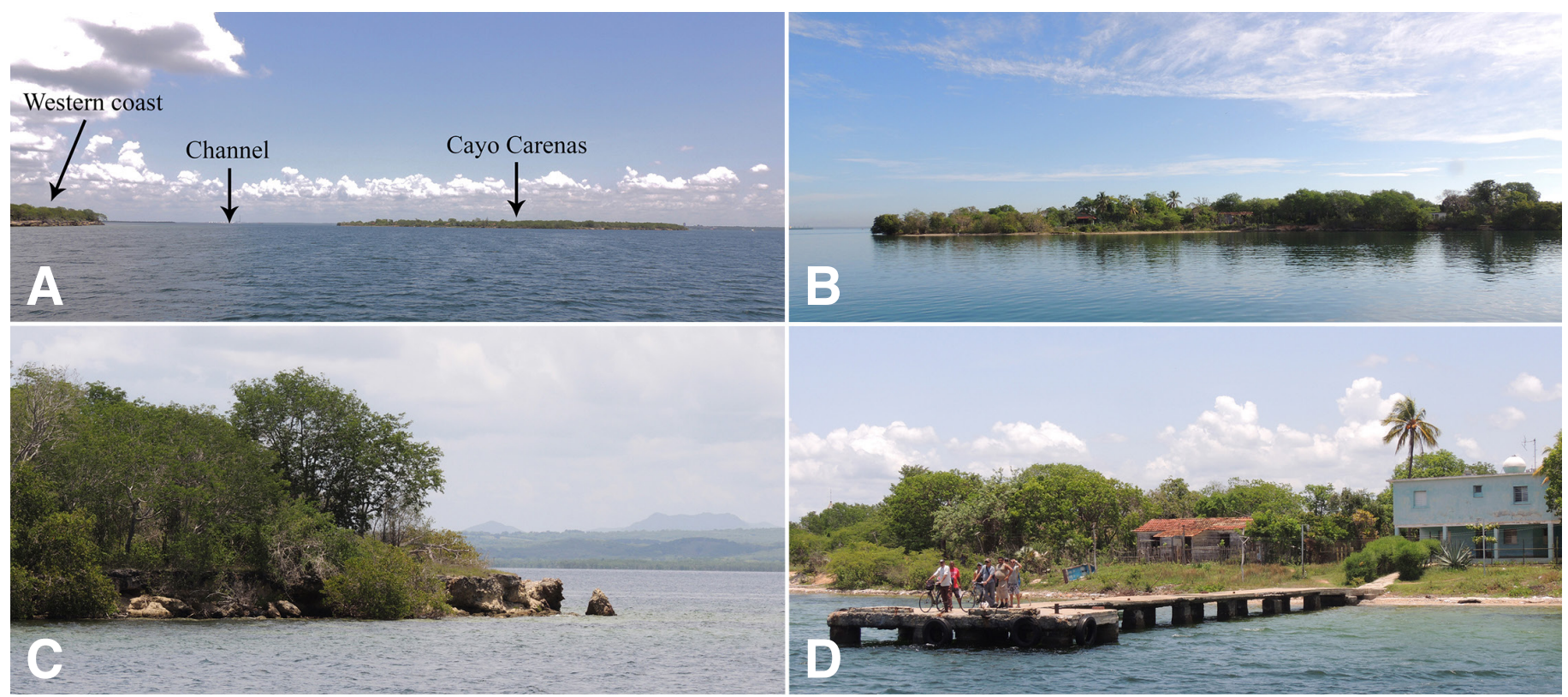

Fig. 2. Different views of Cayo Carenas, Cienfuegos Bay, from the sea: (A) View of the key from the south, (B) Punta Arenas, (C) Punta Pescadores, and (D) the main wharf and some buildings. Photographs (C) T.M. Rodríguez-Cabrera.
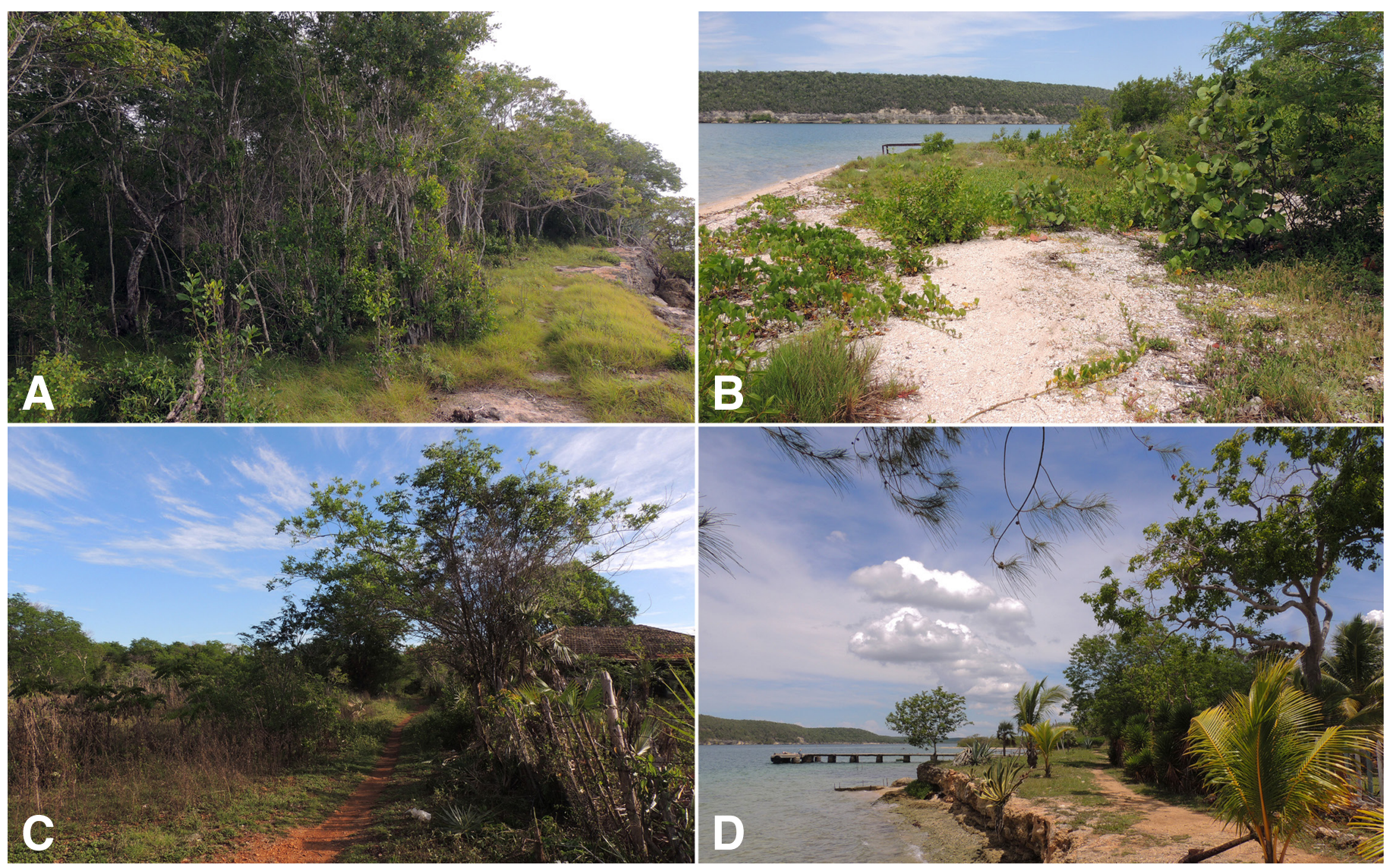

Fig. 3. Different habitats on Cayo Carenas, Cienfuegos Bay: (A) Ecotone between semideciduous forest and rocky-beach vegetation complex, (B) sandybeach vegetation complex at Punta Arenas, (C) secondary vegetation in the interior, and (D) a pier along the southwestern coast. Photographs (C) T.M. Rodríguez-Cabrera. 
forest, which covers about $70 \%$ of the key (Fig. 3A), although a sandy-beach vegetation complex occurs at Punta Arenas (Fig. 3B) and a rocky-beach vegetation complex at Punta Piedras and along the southeastern coast (Fig. 3A). Secondary vegetation has increased in many areas, particularly around human buildings (Fig. 3C, D). Small, isolated elements of mangrove (Rhizophora, Avicennia) and Sea Grape (Coccoloba uvifera) can be found throughout the perimeter of the key. Only a few of the approximately 20 human buildings (Fig. 2D) are permanently inhabited by local residents, the others are used sporadically by fishermen and vacationers.

We conducted three surveys on 3 June, 7 July, and 9 August 2016, actively searching across all vegetation types during both day and night. By day, we checked under stones, under tree bark, and inside hollow logs and old termite nests. At night, we walked slowly through the forest using headlamps until about midnight. We also interviewed local residents regarding the herpetofauna. The relative abundance of different species was classified according to the following criteria: Rare ( $<5$ individuals/survey), abundant (5-10 individuals/survey), and very abundant (>10 individuals/survey).
Results

We found a total of 12 reptilian species belonging to seven families (Table 1: Figs. 4 \& 5). Five species are Cuban endemics and one of them (the Escambray Spotted Sphaero, Sphaerodactylus oliveri) is restricted to the southern coast of central Cuba (Fig. $4 \mathrm{~A}, \mathrm{~B}$; Table 1). Snakes in general were rarely observed, as was $S$. oliveri. We found one incomplete shed skin of an indeterminate species of Amphisbaena under a rock in semideciduous forest. All species were in both semideciduous forest and secondary vegetation, except $S$. oliveri and Amphisbaena, which were observed only in semideciduous forest. Terrestrial lizards in the genera Leiocephalus and Pholidoscelis were particularly abundant in more open areas near to the shoreline. Human buildings offered additional refuges for species including Anolis sagrei, L. carinatus, and $S$. argus, which are more tolerant to disturbance.

Local residents told us that the Cuban Boa (Chilabothrus angulifer; Boidae) and the Cuban Iguana (Cyclura nubila; Iguanidae) had been introduced recently as tourist attractions, but we were unable to confirm their presence. We found no evidence of amphibians, but local residents mentioned the presence of toads (Peltophryne sp.).

Table 1. Reptilian species found on Cayo Carenas, Cienfuegos Bay, Cuba. Abundance: $\mathrm{R}=$ rare $(<5$ individuals/survey), $\mathrm{A}=\mathrm{abundant}(5-10$ individuals/survey), VA = very abundant (>10 individuals/survey). Status: $\mathrm{E}=$ endemic, $\mathrm{N}=$ native non-endemic, $\mathrm{I}=\mathrm{introduced}$.

\begin{tabular}{llll} 
Taxon & Common Name & Abundance & Status \\
\hline SPHAERODACTYLIDAE & & & \\
\hline Sphaerodactylus oliveri & Escambray Spotted Sphaero & $\mathrm{R}$ & $\mathrm{E}$ \\
\hline Sphaerodactylus argus & Jamaican Stippled Sphaero & $\mathrm{A}$ & $\mathrm{I}$ \\
\hline TEIIDAE & Cuban Whiptail & $\mathrm{VA}$ & $\mathrm{N}$ \\
\hline Pholidoscelis auberi & & $\mathrm{VA}$ & $\mathrm{N}$ \\
\hline LEIOCEPHALIDAE & Saw-scaled Curlytail & $\mathrm{A}$ & $\mathrm{E}$ \\
\hline Leiocephalus carinatus & Cuban Brown Curlytail & $\mathrm{A}$ & $\mathrm{N}$ \\
\hline Leiocephalus cubensis & & $\mathrm{A}$ & $\mathrm{E}$ \\
\hline DACTYLOIDAE & Cuban Twig Anole & $\mathrm{N}$ \\
\hline Anolis angusticeps & Cuban Green Anole & $\mathrm{VA}$ & \\
\hline Anolis porcatus & Cuban Brown Anole & $\mathrm{E}$ \\
\hline Anolis sagrei & & $\mathrm{R}$ & \\
\hline AMPHISBAENIDAE & Amphisbaena & $\mathrm{R}$ & $\mathrm{N}$ \\
\hline Amphisbaena sp. & & $\mathrm{R}$ \\
\hline DiPSADIDAE & Cuban Racer & $\mathrm{R}$ & $\mathrm{E}$ \\
\hline Cubophis cantherigerus & Cuban Lesser Racer & \\
\hline Caraiba andreae & Yellow-banded Trope & \\
\hline TrOPIDOPHIDAE & & $\mathrm{R}$ & \\
\hline Tropidophis semicinctus & & \\
\hline
\end{tabular}



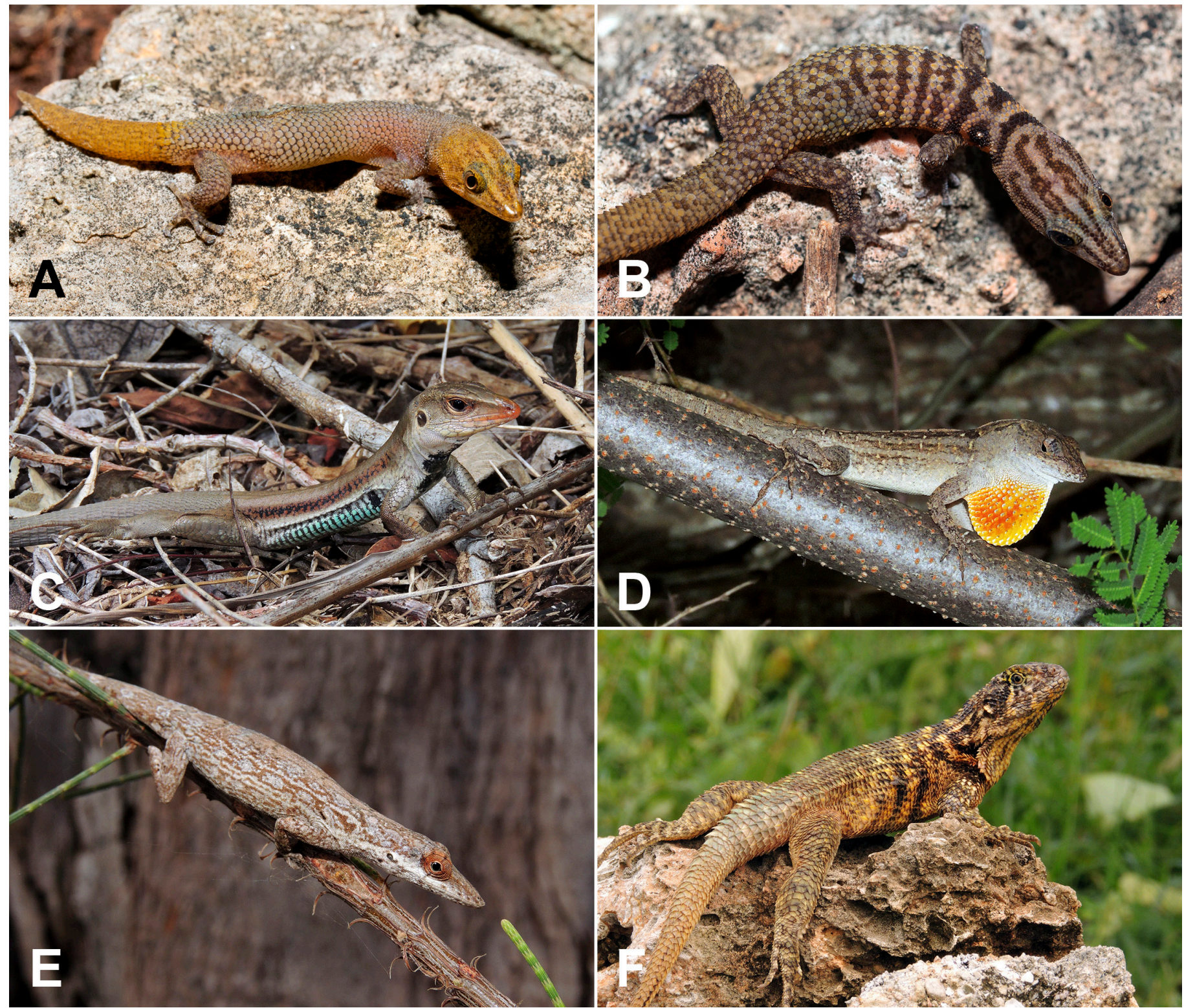

Fig. 4. Some reptilian species found at Cayo Carenas, Cienfuegos Bay: (A \& B) Male and female Escambray Spotted Sphaero (Sphaerodactylus oliveri), (C) male Cuban Whiptail (Pholidoscelis auberi atrothorax), (D) male Cuban Brown Anole (Anolis sagrei), (E) female Cuban Twig Anole (Anolis angusticeps), and (F) male Saw-scaled Curlytail (Leiocephalus carinatus labrossytus). Photographs (C) R. López-Silvero (A, B) and T.M. Rodríguez-Cabrera (C, D, E, F).

\section{Discussion}

The apparent absence of amphibians on Cayo Carenas likely is attributable to a lack of permanent freshwater and/or humid microhabitats suitable for reproduction. This is consistent with the results of Garrido's $(1969,1973)$ surveys of other small Cuban keys, where the only amphibian observed, albeit in very low densities, was the Cuban Treefrog (Osteopilus septentrionalis). We do not discount the possible occurrence of the latter on Cayo Carenas. However, if present, it probably exists at a very low population density, depending on small temporary pools in limestone holes for reproduction.

Two subspecies of the Cuban Whiptail (Pholidoscelis auberi; Fig. 4C), which differ greatly in color pattern, occur around Cienfuegos Bay: P. a. peradusta on the western side and $P$. a. atrothorax on the eastern side toward Trinidad (Fig. 6; Schwartz 1970a). The dispersal ability of $P$. auberi appears to be limited and highly influenced by seemingly minor geographic barriers such as bays, rivers, narrow sea channels, and other factors like edaphic conditions (Schwartz 1970b). This is reflected in the strong geographic variation observed in the species, which has led to the description of 40 subspecies in Cuba and the Bahamas (Schwartz 1970a, 1970b; Henderson and Powell 2009; Buckner et al. 2012; Estrada 2012). The four rivers that flow into Cienfuegos Bay (Fig. 1) appear to function as barriers between the subspecies (Fig. 6), and similar situations were described by McCoy (1970) and Schwartz (1970a, 1970b). Although Cayo Carenas originated as a fragment of the western side of the bay from which it is sepa- 


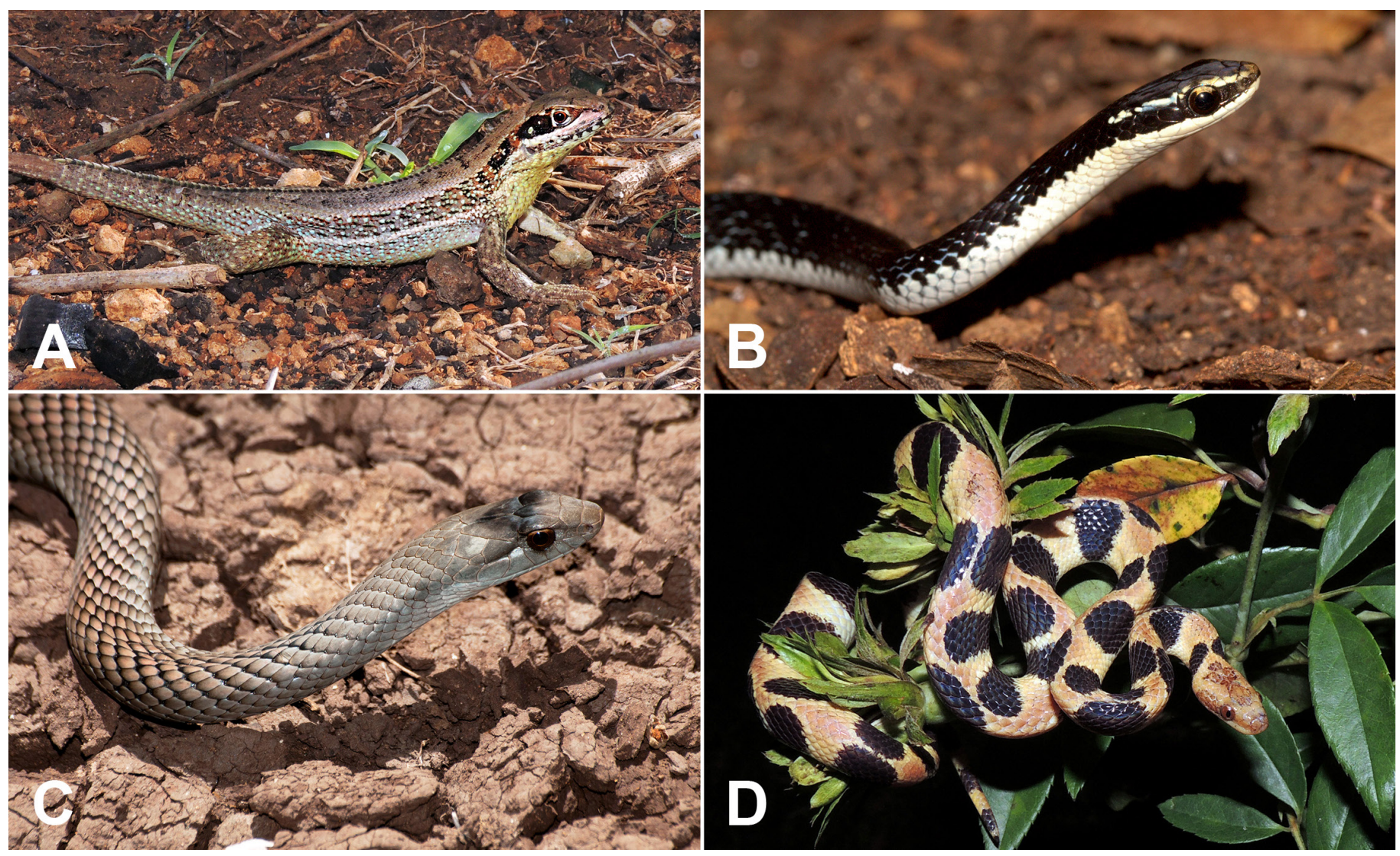

Fig. 5. Additional reptilian species found at Cayo Carenas, Cienfuegos Bay: (A) Male Cuban Brown Curlytail (Leiocephalus cubensis), (B) juvenile Cuban Lesser Racer (Caraiba andreae andreae), (C) female Cuban Racer (Cubophis cantherigerus cantherigerus), and (D) female Yellow-banded Trope (Tropidophis semicinctus). Photographs (C) T.M. Rodríguez-Cabrera (A, D), Ruben Marrero (B), and R. López-Silvero (C).

rated by a mere $0.5 \mathrm{~km}$ (Fig. 1), the subspecies that occurs here is $P$. a. atrothorax. The most reasonable explanation for such an unexpected distribution might be vicariance instead of overwater dispersal. The channel dividing Cayo Carenas and the western shore of the bay is nearly $40 \mathrm{~m}$ deep. On the other hand, a band of very shallow $(<2 \mathrm{~m})$ water separates Cayo Carenas and Punta de la Cueva on the eastern side of the bay (Fig. 1); that area might well have been emergent and functioning as a land bridge until very recently. The continuous rise in sea levels since the last glacial maximum (Iturralde-Vinent 2003, 2005) probably isolated this key from the western side of the bay some 11,000-12,000 years ago, whereas the eastern side might have remained in contact with the mainland until only 7,000-8,000 years ago. This key apparently became detached from the mainland before or when a $P$. peradusta + atrothorax stock still inhabited the entire region. When sea levels rose and flooded the western channel and other deeper areas of the Cienfuegos bay about

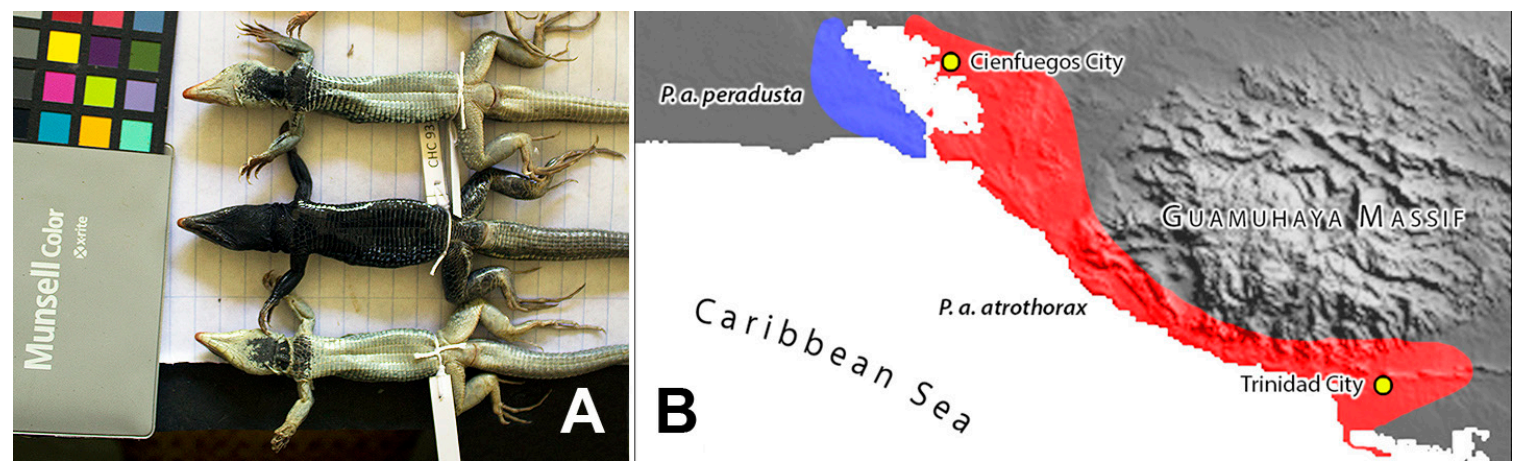

Fig. 6. (A) Ventral views of two subspecies of Cuban Whiptails: Pholidoscelis auberi peradusta (center) from the western side of Cienfuegos Bay and $P$. $a$. atrothorax (top and bottom) from the eastern side of the bay. Photograph (C) J. Torres. (B) Map depicting the distributions of $P$. a. peradusta and $P$. a. atrothorax in south-central Cuba. Modified after Schwartz (1970a). 
11,000 years ago, the eastern and the western populations of $P$. auberi became separated and began accumulating differences. If this hypothesis is true, it could be used as a model of rapid evolution. A thorough phylogeographic study would be necessary to elucidate the evolutionary history of the lizards in the genus Pholidoscelis in this region.

The occurrence on Cayo Carenas of other organisms like the tree snail Liguus fasciatus goodrichi (TMRC, pers. obs.; Fig. 7), a land mollusk with a very low tolerance of salt water and previously known only from around the Jagua Fortress on the southwestern side of the bay (Clench 1934), suggests that the fauna of this key has multiple origins, some attributable to vicariance and others to overwater dispersal. The snail population might have become separated from that of the mainland when the fragment today forming Cayo Carenas became detached, but we cannot rule out an arrival via rafts formed of tree branches and carried into the bay by high tides or hurricanes. However, the latter do not explain the current distribution of $P$. auberi, for which the land-bridge hypothesis seems more plausible.

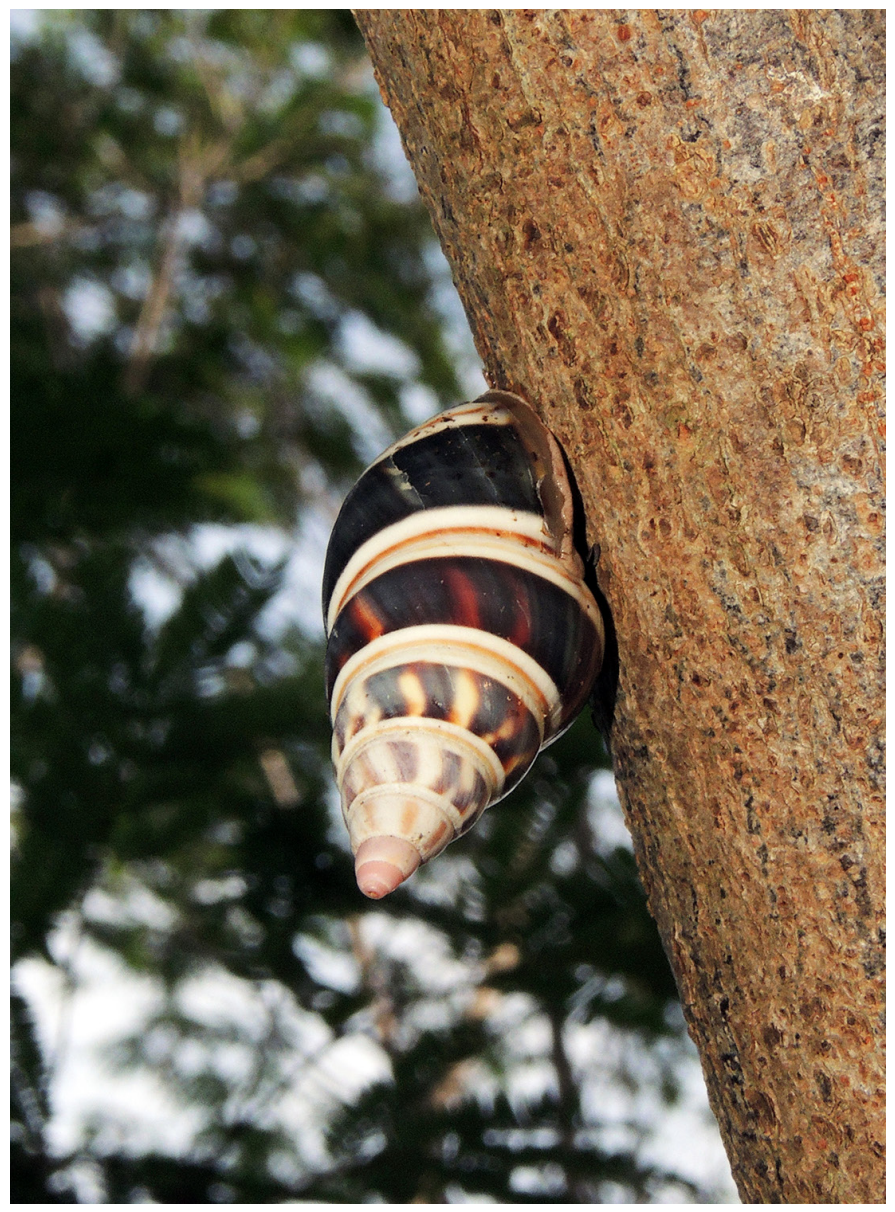

Fig. 7. The Cuban Tree Snail (Liguus fasciatus goodrichi) was previously known only from the southwestern side of Cienfuegos Bay, Cuba. Its occurrence on Cayo Carenas seems better explained by vicariance than by overwater dispersal. Photograph (C) T.M. Rodríguez-Cabrera.
Cienfuegos Bay might also have functioned as an important geographic barrier during the evolutionary history of Sphaerodactylus oliveri. This species was listed as Vulnerable in the Red Book of Cuban Vertebrates (Rodríguez and Díaz 2012), largely due to its very small range along the southern Cienfuegos coast to the east of the bay and on some keys in the Archipiélago de los Canarreos (Rodríguez et al. 2013). Nevertheless, a very similar species ( $S$. richardi) occurs in the middle of the range of $S$. oliveri. We have observed a gradient in color pattern along the coast, ranging from the $S$. oliveri form (stippled in both sexes) in the east to the $S$. richardi form (plain in males and banded in females) to the west of the bay (which suggests that $S$. richardi and S. oliveri might be conspecific). The color pattern of geckos on Cayo Carenas consists of very faded, almost absent spots in males and banded females, which coincides with patterns seen around the Jagua Fortress on the western side of the bay. Because of this intermediate color pattern between S. richardi and S. oliveri and due to the close proximity to the latter, we rather tentatively refer the population from Cayo Carenas to S. oliveri. Again, the use of molecular tools would be helpful in elucidating species boundaries within this group.

We observed only three relatively small, widely distributed generalist anoline species (Table 1). The apparent absence of giant anoles (either crown-giant or twig-giant ecomorphs) might be attributable to the small area of the key and its limited productivity (e.g., Brown and Lomolino 1998; McNab 1994; Lomolino et al. 2010), which could limit food availability, especially for large arboreal anoles with relatively high energy requirements. The largest lizard we found on this key was Leiocephalus carinatus (Fig. 4F), a ground-dwelling species that exploits a wide variety of trophic resources, including small insects (mainly ants and termites), crustaceans (small crabs), arachnids, other lizards (including the Cuban Brown Anole, Anolis sagrei, which was very abundant), and vegetable matter (Schoener et al. 1982; Armas 1987; Fong and Garcés 2002; see Henderson and Powell 2009 for a review). Crustaceans in particular are abundant on this key (TMRC, pers. obs.). On small islands with low productivity an important portion of the available energy usually comes from marine food webs via shore drifts and seabird colonies (Polis and Hurd 1995). Leiocephalus carinatus and other terrestrial lizards might be taking advantage of such resources by foraging in flotsam and stranded seaweeds.

The Yellow-banded Trope (Tropidophis semicinctus; Fig. 5D) is an arboreal nocturnal constricting snake distributed throughout much of the Cuban Archipelago, although only a few records are from outside the main island, and all of those are restricted to the northern coast (Rodríguez et al. 2013). Its occurrence on Cayo Carenas constitutes the first record of the species outside the main island along the southern coast of Cuba. This species apparently specializes in hunting small 
sleeping anoles such as A. sagrei (Fig. 4D; Rodríguez-Cabrera et al., in prep.).

However, the general rarity of snakes on the key probably reflects their role as top predators in less complex ecosystems. The Cuban Racer (Cubophis cantherigerus; Fig. 5C) and the Cuban Lesser Racer (Caraiba andreae; Fig. 5B) are diurnally active foragers that feed on a wide variety of vertebrates, including lizards (see Henderson and Powell 2009 for a review), which are relatively abundant on the key. Nonetheless, lizards apparently are not sufficiently abundant to support large snake populations.

Although more surveys will be necessary to better understand the herpetofauna of Cayo Carenas, this is a first step that could serve to call attention to the species inhabiting this key. Properly managed, Cayo Carenas could function as a natural refuge for several threatened endemic species.

\section{Acknowledgements}

We thank Julio León for assistance in the field and the administration of the Cienfuegos Botanical Garden for logistical support. Raimundo López-Silvero and Ruben Marrero provided photographs.

\section{Literature Cited}

Armas, L.F. de. 1987. Notas sobre la alimentación de Leiocephalus carinatus cayensis (Sauria: Iguanidae). Poeyana 350: 1-7.

Brown J.H. and M.W. Lomolino (eds.). 1998. Biogeography. 2nd ed. Sinauer Associates, Inc., Sunderland, Massachusetts.

Buckner, S.D., R. Franz, and R.G. Reynolds. 2012. Bahama Islands and Turks \& Caicos Islands, pp. 93-110. In: R. Powell and R.W. Henderson (eds.), Island lists of West Indian amphibians and reptiles. Bulletin of the Florida Museum of Natural History 51: 85-166.

Clench, W.J. 1934. New mollusks in the genus Liguus from Cuba and the Isle of Pines. West Indian mollusks no. VIII. Occasional Papers of the Boston Society of Natural History 8: 101-124.

Estrada, A.R. 2012. The Cuban Archipelago, pp. 113-125. In: R. Powell and R.W. Henderson (eds.), Island lists of West Indian amphibians and reptiles. Bulletin of the Florida Museum of Natural History 51: 85-166.

Fong G., A. and G. Garcés G. 2002. Composición y variación estacional de la dieta de Leiocephalus carinatus (Sauria: Iguanidae) en Santiago de Cuba, Cuba.
Boletin de la Sociedad Herpetológica Mexicana 10(2): 29-34.

Garrido, O.H. 1969. Anfibios, reptiles y aves de Cayo Cantiles. Poeyana 67(serie A): 1-44.

Garrido O.H. 1973. Anfibios, reptiles y aves de Cayo Real (Cayos de San Felipe), Cuba. Poeyana 119: 1-50.

Henderson, R.W. and R. Powell. 2009. Natural History of West Indian Amphibians and Reptiles. University Press of Florida, Gainesville, Florida.

Iturralde-Vinent, M.A. 2003. Ensayo sobre la paleogeografía del Cuaternario de Cuba, pp. 54-74. In: Memorias GEOMIN'2003 (V Congreso Cubano de Geología y Minería). La Habana, Cuba.

Iturralde-Vinent, M.A. 2005. La paleogeografía del Caribe y sus implicaciones para la biogeografía histórica. Revista del Jardín Botánico Nacional 25-26: 49-78.

Lomolino, M.V., J.H. Brown, and D.F. Sax. 2010. Island Biogeography Theory. Reticulations and Reintegration of "a Biogeography of the Species," pp. 13-51 In: J.B. Losos and R.E. Ricklefs (eds.), The Theory of Island Biogeography Revisited. Princeton University Press, Princeton, New Jersey.

McCoy, C.J. 1970. A systematic review of Ameiva auberi Cocteau (Reptilia, Teiidae) in Cuba and the Bahamas. II. The Bahamian subspecies. Annals of the Carnegie Museum 41: 118-151.

McNab, B.K. 1994. Resource use and the survival of land and freshwater vertebrates on oceanic islands. American Naturalist 144: 643-660.

Polis, G.A. and S.D. Hurd. 1995. Extraordinarily high spider densities on islands: Flow of energy from the marine to terrestrial food webs and the absence of predation. Proceedings of the National Academy of Sciences of the United States of America 92: 4382-4386.

Powell, R. and R.W. Henderson (eds.). 2012. Island lists of West Indian amphibians and reptiles. Bulletin of the Florida Museum of Natural History 51: 85-166.

Pushcharovsky, Y.M. (ed.). 1988. Mapa geológico de la República de Cuba a escala 1:250,000. Academias de Ciencias de Cuba, La Habana, and the USSR Academy of Sciences, Moscow, Russia.

Rodríguez Schettino, L. and L.M. Díaz. 2012. Sphaerodactylus oliveri, pp. 149150. In: H. González Alonso, L. Rodríguez Schettino, A. Rodríguez, C.A. Mancina, and I Ramos García (eds.), Libro Rojo de los Vertebrados de Cuba. Editorial Academia, La Habana, Cuba.

Rodríguez Schettino, L., C.A. Mancina, and V. Rivalta González. 2013. Reptiles of Cuba: Checklist and geographic distributions. Smithsonian Herpetological Information Service 144: 1-96.

Schoener, T.W., J.B. Slade, and C.H. Stinson. 1982. Diet and sexual dimorphism in the very catholic lizard genus Leiocephalus of the Bahamas. Oecologia 53: 160-169.

Schwartz, A. 1970a. A systematic review of Ameiva auberi Cocteau (Reptilia, Teiidae) in Cuba and the Bahamas. I. The Cuban subspecies. Annals of the Carnegie Museum 41: 45-117.

Schwartz, A. 1970b. A systematic review of Ameiva auberi Cocteau (Reptilia, Teiidae) in Cuba and the Bahamas. III. Discussion. Annals of the Carnegie Museum 41: 152-168.

Uetz, P., P. Freed, and J. Hošek (eds.). 2018. The Reptile Database (http://www. reptile-database.org). 